\title{
Conclusion: Uncertain Outcomes of Conflict and Negotiation
}

\author{
Lowell Turner
}

Where does all this leave us? There are some things we can say with reasonable certainty, with consensus at least among the authors of this volume. Social partnership as a framework for the regulation of a market economy has in the past been considerably successful, in the Federal Republic of Germany and elsewhere, in terms of both economic results and workplace democracy. ${ }^{1}$ Although in the wake of German unification and other global market challenges, social partnership in Germany finds itself in crisis, all is not lost. With varying degrees of optimism, the authors of this book agree that reform and adaptation are possible, starting from existing institutions, given appropriate actor strategies aimed at both institutional reform and innovative policy. Much depends not only on innovative strategy but also on the outcomes of conflict and negotiation among key actors in business, labor, and government. This is, therefore, a moment of great uncertainty, of possibly decisive historical contingency, when alternative scenarios are possible. The openness and pivotal nature of future outcomes for a unified Germany are points on which both historical institutionalists (who emphasize the shaping power of institutions and their constraints) and political constructionists (who emphasize political processes of conflict and negotiation) can agree. ${ }^{2}$

I. For other cases of enduring and successful social partnership, consider, for example, Austria (Tomandl and Fuerboeck I986) and Denmark (Dues, Jensen, and Jesper 1994).

2. See Locke and Thelen 1995 and forthcoming for a useful theoretical presentation of the contrasting perspectives of historical institutionalists and political constructionists in the social sciences-as well as the possibilities for mutual learning and synthesis. 
To elaborate on each of these points, the findings presented in this book can be summarized as follows. First of all, the German model, that is, a social partnership approach to the negotiation of terms and conditions for the organization of an advanced market economy has worked in the past. ${ }^{3}$ We believe, on the basis of extensive collective research on different aspects of the political economy of the Federal Republic, both before and after unification, that the preservation of a reformed social partnership in Germany is highly desirable as an alternative to less regulated forms of capitalism in the contemporary world economy. Thus we disagree rather sharply with both conservative and liberal analysts who see the social market economy as an expensive and outdated relic of a welfare-state past. ${ }^{4}$

The evidence presented in this book also shows not only that social partnership is desirable but that it remains relatively intact. We have identified problems that must be solved for this to continue to be the case, but whatever the future holds, the basic institutions and practices of social partnership have been transferred into eastern Germany and continue to characterize political-economic relations in unified Germany. This remains true even in the face of major challenges presented by European integration, intensified global competition, a rapidly appreciating deutschmark, market imperatives for production reorganization (driven by Japanese-style lean production), and escalating collective bargaining conflict. Both employer associations and unions continue to play pattern-setting roles in wage negotiations, to set the framework for firm-level codetermination, and to engage in national, regional, and local negotiations over important aspects of economic and labor-market policy.

The authors also agree, however, that these combined pressures have been exceptionally strong in the r990s and pose major challenges for the survival of the German model. Although the doomsayers of the I970s and I980s turned out to be wrong, failure appears well within the range of plausible outcomes in the coming years. None of the following, for example, are inconceivable under present and future circumstances: (I) that large numbers of small and medium-sized firms could leave the employer associations, rendering collective bargaining and other social partner-negotiated outcomes less and less comprehensive; (2) that employer associations could continue and even intensify their attacks on union influence, both undermining the unions and destabilizing the social partnership; (3) that by

3. For a comprehensive pre-unification analysis that reaches a similar conclusion concerning the viability of negotiated adjustment, see Katzenstein 1989. For a concise post-unification analysis in the same vein, see Goodhart 1994.

4. See, for example, a steady stream of rather one-sided editorials in the Wall Street Journal of recent years. 
failing to resolve internal East-West and other tensions and by failing to develop appropriate strategies to organize the growing ranks of white-collar professional, technical, and service workers, unions will eventually begin to lose major collective bargaining conflicts (as they have so far avoided doing) and will embark on an irreversible and prolonged decline in membership density; and (4) that because of conservatism or paralyzing conflict, employers, unions, and government, together or singly, will fail to find adequate solutions to particular pressing problems such as technology innovation, production reorganization, long-term unemployment, vocational training reform, and macroeconomic policy demands. Any of these problems, if unsolved, could reach crisis proportions and result in a serious weakening of the German social partnership.

Even the most pessimistic among us, however, believe that it is within the capacities of the social partners to solve such problems. Successful adaptation, we contend, lies within the range of choice set by institutions and the possibilities for institutional reform. This conviction runs contrary to more pessimistic analyses that identify or predict the decline of German unions and/or the social partnership under almost any foreseeable scenario (Mahnkopf I991 and 1993; Streeck 1991 and 1997). Our findings concerning the past performance and flexibility of German institutions of bargaining, coupled with the perception that contemporary actors do have meaningful choices to make, lead us away from such hopelessness. Precisely because the institutions are flexible, because they allow regularized and complementary bargaining ranging from national, regional, and local-level policymaking processes, to comprehensive collective bargaining, to firm and plant-level negotiated codetermination, their capacity to solve new problems is strong. This does not mean they will solve these problems, but our analyses lead us to believe that solutions to the problems we have identified lie within the capacities of existing institutions, either as they are or as they could be reformed by contemporary actors.

Three examples, in addition to the evidence already presented throughout this book, illustrate how actor strategies and reform efforts are addressing contemporary challenges. First, as both Herrigel and Wever have argued, input and negotiation need to move in a more regularized way from the "functional level" down to the point of production. Astute and experienced analysts of German industrial relations, Walther Müller-Jentsch and HansJoachim Sperling (I995) suggest that this is precisely what is happening in German firms today; so much so in fact that the dual system (collective bargaining and codetermination) is evolving into a flexible "triple system," one that includes greatly expanded employee participation in daily, ongoing workplace decision making. Whether such negotiation can solve the major 
problems of reorganization that Herrigel and Wever identify remains to be seen, but the shifting locus of negotiation indicates a fundamental institutional reform that makes such adaptation possible.

Another example is afforded by the increasing openness of IG Metall to bargaining innovations (such as flexibility in working hours and corresponding compensation) as well as the escalation of internal reform efforts within this most important of German unions. On June I5-16, I995, for example, IG Metall invited academic speakers Wolfgang Streeck, Horst Kern, and Klaus Offe to a two-day workshop led by the union's top two leaders (Klaus Zwickel and Walther Riester), to speak openly about serious problems facing the German labor movement. With a focus on the development of a process of internal organizational development (OrganisationsEntwicklung), IG Metallers engaged in active debate and discussed openly the problems identified by their guest speakers. At least two principal innovations in union thinking point toward possible adaptation of the sort that our research indicates is necessary: $(\mathrm{I})$ a growing commitment to rank-andfile participation, both at the workplace and in the life of the union; and (2) a growing openness to a more flexible menu of alternative, firm-level bargaining outcomes (within a comprehensive collective bargaining framework).

A final example can be seen in current internal reform processes within the metalworking employers' federation, Gesamtmetall. This is particularly salient in the wake of the 1995 bargaining round. Both inside and outside the organization, Gesamtmetall leadership was widely perceived to have made a series of bargaining blunders that contributed to a (perhaps unnecessary) strike in Bavaria, massive worker/union solidarity, and a clear union victory in the final settlement. Internal criticism and leadership changes resulting from the 1995 fiasco may well lead to (I) a better awareness of the dubious wisdom of a strategy that aims to defeat IG Metall and (2) innovative and flexible strategies that aim toward realistic compromise to better serve the interests of employer association membership. This conclusion was reinforced by an important IG Metall victory in the sick-pay dispute of fall 1996 and the subsequent contract settlements of 1996-97.

If necessary reform and adaptation are within the range of institutional possibility, then the critical variable becomes actor strategy, along with the outcomes of conflict and negotiation among major actors. Strategies, of course, are limited both by broader economic circumstances (such as the appreciation of the deutschmark, which may price some German products out of world markets no matter how extensive firm-level reform may be) and by institutional constraints. Not all things are possible. Within the limits of circumstance and structure, however, actor strategies become decisive.

Here we reach the frontiers of contemporary social science research. We know much more about institutions, their development and consequences, 
than we do about the political processes that lead actors to choose certain strategies at the expense of others and that result in the resolution of conflict and negotiation. ${ }^{5}$ We know that actor strategies are in part shaped by the institutional framework (Hall I986); but we also know that actor choices are shaped by interests, identities, and leadership decisions not entirely determined by the institutions. ${ }^{6}$ Obviously, actors make their own choices in part in response to initiatives taken by other actors. What we do not know, however, is how these and other factors combine to determine the choices that an employers' association or labor union will make in a given situation. Nor can we necessarily predict the outcomes of conflict and negotiation from actor interests, identities, the institutional framework, or even the conflicting choices that actors might make. Too much depends on the uncertain and often surprisingly unpredictable political processes of conflict and negotiation.

Thus we end up humbled not only by the sometimes contradictory yet equally persuasive analyses presented in this book and elsewhere but also by the most fundamental limits to our ability to predict the future-and especially to predict the choices that even well-organized human agents will make and the complicated means by which they will resolve their differences among themselves and with other equally organized human agents.

Although we cannot predict the future (this luxury is reserved for those who extrapolate from the past, and they are quite often wrong), proponents of social partnership in a prosperous and democratically stable unified Germany can take heart from this analysis. While the challenges are severe, the institutions have so far demonstrated a basic resilience. Continuing reform, as we have seen, is essential to the post-unification vitality of the German model. Prospects for successful adaptation and reform now reside squarely in the hands of key, well-organized actors in German business, labor, and government. The adaptation of social partnership to the most challenging circumstances of the late twentieth century and beyond is quite possibly within their grasp, but so is the failure of adaptation and the decline of social partnership.

\section{REFERENCES}

Due, Jessper, Jørgen Steen Madsen, Carsten Strøby Jensen, Lars Kjerulf Petersen. 1994. The Survival of the Danish Model. A Historical Sociologi-

5. For some of the best contemporary research on the importance of institutions, see March and Olsen 1989; Hall 1986; Streeck 1992; and Steinmo, Thelen, and Longstreth 1992.

6. See Sabel 1992, Locke 1995, and Herrigel 1996 for persuasive and well-researched perspectives that emphasize identities and local networks. 
cal Analysis of the Danish System of Collective Bargaining. Copenhagen: Jurist-og Økonomforbundets Forlag, DJØF Publishing.

Goodhart, David. 1994. The Reshaping of the German Social Market. London: Institute for Public Policy Research.

Hall, Peter A. 1986. Governing the Economy: The Politics of State Intervention in Britain and France. New York: Oxford University Press.

Herrigel, Gary. 1996. Industrial Constructions. The Sources of German Industrial Power. New York: Cambridge University Press.

Hoffmann, Reiner, Otto Jacobi, Berndt Keller, and Manfred Weiss, eds. 1995. German Industrial Relations under the Impact of Structural Change, Unification and European Integration. Düsseldorf: HansBöckler-Stiftung.

Katzenstein, Peter J., ed. 1989. Industry and Politics in West Germany: Toward the Third Republic. Ithaca: Cornell University Press.

Locke, Richard M. 1995. Remaking the Italian Economy. Ithaca: Cornell University Press.

Locke, Richard M., and Kathleen Thelen. 1995. "Apples and Oranges Revisited: Contextualized Comparisons and the Study of Comparative Labor Politics." Politics and Society 23, no. 3: 337-67.

- Forthcoming. The Shifting Boundaries of Labor Politics. Cambridge: MIT Press.

Mahnkopf, Birgit. 1991. "Vorwärts in die Vergangenheit? Pessimistische Spekulationen über die Zukunft der Gewerkschaften in der neuen Bundesrepublik." In Westphal et al. I991, 269-94.

- 1993. "The Impact of Unification on the German System of Industrial Relations." Discussion Paper FS I 93-IO2, Wissenschaftszentrum Berlin für Sozialforschung.

March, James, and Johan Olsen. 1989. Rediscovering Institutions. New York: Free Press.

Müller-Jentsch, Walther, and Hans Joachim Sperling. I995. "Towards a Flexible Triple System? Continuity and Structural Changes in German Industrial Relations." In Hoffmann et al. 1995, 9-29.

Steinmo, Sven, Kathleen Thelen, and Frank Longstreth. 1992. Structuring Politics: Historical Institutionalism in Comparative Analysis. Cambridge: Cambridge University Press.

Streeck, Wolfgang. 1991. "More Uncertainties: German Unions Facing 1992." Industrial Relations 30, no. 3: 317-49.

- 1992. Social Institutions and Economic Performance: Studies of Industrial Relations in Advanced Capitalist Societies. London: Sage.

- I997. "German Capitalism: Does It Exist? Can It Survive?" New Political Economy, forthcoming.

Tomandl, Theodor, and Karl Fuerboeck. 1986. Social Partnership: The Aus- 
trian System of Industrial Relations and Social Insurance. Ithaca: ILR Press.

Westphal, Andreas, Hansjörg Herr, Michael Heine, and Busch, Ulrich, eds. 1991. Wirtschaftspolitische Konsequenzen der deutschen Vereinigung. Frankfurt: Campus Verlag. 